\title{
Reflective Practice in Times of Covid-19: A Tool to Improve Education for Sustainable Development in Pre-Service Teacher Training
}

\author{
M. Teresa Fuertes-Camacho ${ }^{1, *(D)}$, Carles Dulsat-Ortiz ${ }^{2}$ and Isabel Álvarez-Cánovas ${ }^{3}$ (D) \\ 1 Faculty of Educational Sciences, Universitat Internacional de Catalunya, 08017 Barcelona, Spain \\ 2 Faculty of Humanities and Social Sciences, Universidad Isabel I, 09003 Burgos, Spain; carlos.dulsat@ui1.es \\ 3 Department of Educational Theories and Social Pedagogy, Universitat Autònoma de Barcelona, \\ 08193 Bellaterra, Spain; Isabel.Alvarez@uab.cat \\ * Correspondence: tfuertes@uic.es; Tel.: +34-932-541-800
}

\section{check for} updates

Citation: Fuertes-Camacho, M.T.; Dulsat-Ortiz, C.; Álvarez-Cánovas, I. Reflective Practice in Times of Covid-19: A Tool to Improve Education for Sustainable Development in Pre-Service Teacher Training. Sustainability 2021, 13, 6261. https://doi.org/10.3390/su13116261

Academic Editors: Aurélien Decamps, Benoit Martimort-Asso and Carine Royer

Received: 29 April 2021

Accepted: 26 May 2021

Published: 1 June 2021

Publisher's Note: MDPI stays neutral with regard to jurisdictional claims in published maps and institutional affiliations.

Copyright: (c) 2021 by the authors. Licensee MDPI, Basel, Switzerland. This article is an open access article distributed under the terms and conditions of the Creative Commons Attribution (CC BY) license (https:// creativecommons.org/licenses/by/ $4.0 /)$.

\begin{abstract}
Crisis situations such as the current Covid-19 pandemic are a catalyst for change. This study stresses the need to work towards achieving quality education, and to prepare future teachers in sustainability competencies. The research questions are related to the key competencies necessary to accelerate change and to how to increase awareness and literacy of the SDGs in higher education. A quantitative methodology aimed at improving the training of future teachers who engage in reflective and critical thinking was used. Data were gathered on the level of reflection of students from three Spanish universities. The instrument used, the Reflective Practice Questionnaire, includes concepts defined in the literature related to reflective capacity such as Reflection in Action, Reflection on Action and Reflection with Others. The results of the study provide quantitative data showing a positive impact of reflective practice on future teachers. Education for sustainable development requires participatory methods that motivate and empower students to change their behaviour. Reflective practice must be accompanied by processes of communication and supervision that encourage confidence and the desire to improve. Training future teachers in reflective practice should be a differentiating element to achieve quality education, allowing adaptation to current and future adverse situations.
\end{abstract}

Keywords: Covid-19; sustainable development goals (SDGs); quality education (SDG 4); education for sustainable development (ESD); reflective practice questionnaire (RPQ); critical and reflective thinking; self-awareness; sustainable competencies; pre-service teacher training

\section{Introduction}

The 2030 Agenda for Sustainable Development arises from the need to integrate the principles of education for sustainable development (ESD), as sustainability and education are closely connected. Education is explicitly formulated in Sustainable Development Goal 4 (SDG 4) on quality education and its targets 4.4 and 4.7. This SDG emphasizes the key role of education in attaining ESD, and, as a result, enabling a more sustainable society for all. By 2030, it will be important to increase the number of youth and adults who have relevant skills, including technical and vocational skills, for employment, decent jobs and entrepreneurship [1]. The 2015 Incheon Declaration and Framework for Action for the implementation of SDG 4 establishes a new vision of education and stresses the lifelong learning approach. Achieving the 2030 Agenda also requires a transformative approach of higher education through teaching practices and learning experiences. The research presented in this study is aimed at promoting the improvement of initial teacher training.

The COVID-19 pandemic has affected all aspects of life, and education has not been spared. It has had to respond to the challenges posed by the pandemic. There is no doubt that the negative humanitarian, social and economic impact of the pandemic is 
also going to affect the 2030 Agenda, and this may delay the achievement of many of the SDGs at different levels and in various ways. The United Nations and other expert institutions in sustainable development have predicted this with certainty. In order to cope with the current situation, the need to continue working to achieve quality education, and preparing future teachers in cross-curricular competencies in sustainability that enable adapting to the different needs in a given context is key, as has been highlighted in a United Nations study [2].

Higher education plays a crucial role in promoting a paradigm shift towards sustainable development through the development of self-awareness and critical and reflective thinking as key competencies to analyse one's actions. It is necessary to connect the skills and competencies in sustainability with the labour market to ensure that future professionals become agents of transition towards sustainability. In this study, we collect data with regard to the level of reflection of first-cycle university students from three Spanish universities. The instrument used covers a range of relevant concepts that have been defined in the literature with regard to reflective capacity [3]: Reflection in Action (RiA), Reflection on Action (RoA) and Reflection with Others ( $\mathrm{RwO})$, three processes that are strongly related to the capacity of self-appraisal. The following seven attributes (subscales) are related to reflective capacity (RC) and will be considered in this study: Desire for Improvement (Dfl), Confidence-General (CG), Confidence-Communication (CC), Uncertainty (Unc), Stress interacting with Clients (SIC), Job Satisfaction (JS) and Appraisal of Supervision (AS).

\subsection{Quality Education and Competency Development}

ESD is configured as an integral part of quality education, essential to the concept of lifelong learning as defined in aforementioned SDG 4 [1]. From this perspective, all formal and informal educational institutions at all levels should plan teaching and learning strategies to promote the development of competencies in sustainability. ESD addresses learning content and outcomes holistically and considers active learning and the learning environment as crucial elements for developing key competencies in sustainability. Another innovative aspect of SDG 4 is the importance it gives to learning outcomes, both for entering the world of work and for exercising citizenship in a global and interconnected world. The new vision of education is to transform lives through education, recognising the important role of education as the main driver of development and to achieve the other SDGs [1].

The Bologna Declaration and the creation of new university degrees have highlighted the importance of training and evaluating students by competencies and marked the beginning of the debate regarding the sustainability competencies that university graduates should acquire. However, incorporating sustainability into the curriculum does not only mean to include environmental content in the subject syllabus, but is associated with a paradigm shift in the educational process [4]. ESD aims to develop competencies that empower individuals to critically reflect on their own actions and has to be conceived as an essential part of quality education, intrinsic in the concept of lifelong learning [3]. The following two key competencies are crucial for the progress of sustainable development [5-7].

\subsubsection{Critical and Reflective Thinking Competency}

Ability to question rules, practices and opinions; to reflect on values, perceptions, one's own experiences and actions; and to adopt a position in the discourse of sustainability.

\subsubsection{Self-Awareness Competency}

Self-awareness includes emotional awareness, accurate self-appraisal and self-confidence.

It supposes the ability to reflect on the role of each individual in society; to constantly evaluate and promote the actions one performs oneself. Self-awareness or self-appraisal is one of the key components of emotional intelligence, an essential skill for success at work and in personal life.

There is a general consensus that citizens need key (cross-cultural) competencies that allow them to participate constructively and responsibly in today's world [8]. Com- 
petencies describe the specific attributes individuals need for action and autonomy in different contexts and complex situations. They include cognitive, affective, volitional and motivational elements. They are therefore an interaction between knowledge, capacities and abilities, interests and affective dispositions. Competencies cannot be taught but should be developed by students. They are acquired during action, based on experience and reflection $[9,10]$.

Some studies [11] analyse the importance of teachers as creators of contexts that encourage student motivation and learning through the classroom climate they establish and the support provided to students for the benefit of the teaching and learning process.

\subsection{Process of Reflection in an on Action and Development of Critical Thinking}

Reflective capacity refers to the ability, desire and tendency of students to engage in reflective thought during their academic studies and practices [12]. According to the authors of this study, reflective capacity can be measured through a Reflective Practice Questionnaire (RPQ) that includes Reflection in Action (RiA), Reflection on Action (RoA) and Reflection with Others ( $\mathrm{RwO})$, and all three activate critical thinking that increases self-appraisal competency. Other attributes are related to reflective capacity: Desire for Improvement (Dfl), Confidence-General (CG), Confidence-Communication (CC), Uncertainty (Unc), Stress interacting with Clients (SIC), Job Satisfaction (JS) and Appraisal of Supervision (AS).

The Participatory Action Research method (PAR) as a path to professional development combines two processes, participation and action, both of which combine observation and systematic reflection as a source of knowledge. It is a process that integrates theory and practice, and that enables learning and critical awareness of reality. Questions are the key strategy to bring out professional knowledge (skills): What has surprised me? What have I collected? What do I associate it with? How do I act? These are some examples of the questions that stimulate individual reflection encouraging self-appraisal to define, change or improve.

This process allows building the knowledge of students and teachers through interaction with the learning experience of practice and the theoretical knowledge acquired through an internal process of construction of meanings and grounded representations. According to Schön [13], the practitioner reflects on the phenomenon before him, and on the prior understandings that have been implicit in his behaviour.

Reflection on Action (RoA) occurs after the event $[13,14]$ and refers to the focus. Reflection in Action (RiA) takes place during the process and refers to the context. In both processes, we explore what happens or happened while acting, why we behaved as we did, and what could happen or could have happened for the other. We thus fully process our experiences, we associate our experiences with what happens or has happened before, and with our theories, and in doing so, we improve our understanding of the situation. This process, according to Schön [15], involves an inquiry carried out by students at an individual and collaborative level, with teachers or classmates (reflection with others-RwO) in order to improve the training process, following these steps (Figure 1):

1. Description of the experience.

2. Reflection, and individual and shared analysis of the experience.

3. Abstraction and application of content and theoretical principles to the teaching practice.

4. Evaluation of the experience, what general and specific conclusions can be drawn, followed by any action plan and evaluation of learning from the experience. 


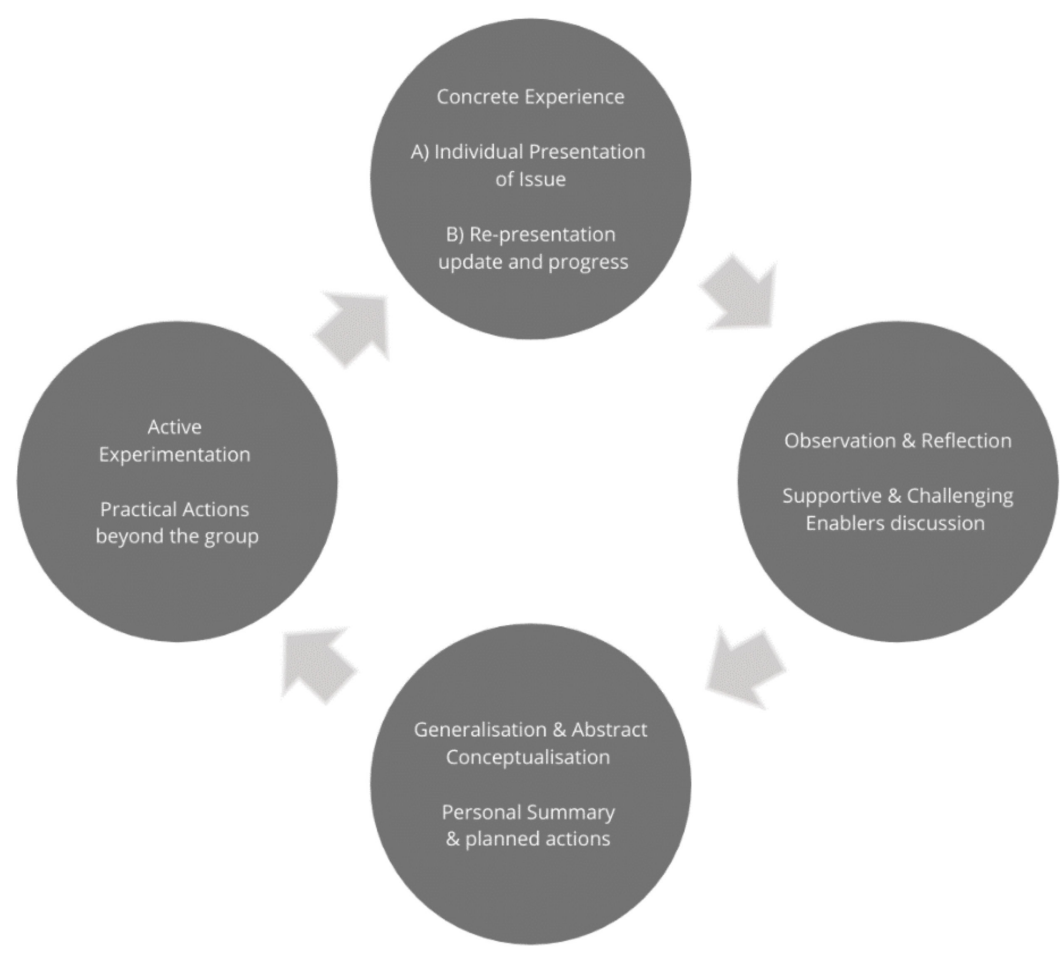

Figure 1. Cycles of reflection on practice based on Schön [13].

\subsection{Reflection as an Essential Element in the Development of Skills in Initial Teacher Training}

The use of reflective practice should be introduced into teacher training programmes [16]. There are several studies on the development of reflective capacity in university students in health-related practices [17]. Its use in professional degrees is considered important, although teachers must be equipped with tools and strategies that facilitate incorporating this reflective practice in the classroom. Different research studies stress the need to start reflective practice from the first years of training as it contributes to building theoretical knowledge from practice from the beginning [18-20]. Reflective practice is positive as long as deep, non-superficial learning strategies are used [8,21-23]. It should be used in both initial and continuing training during professional development.

Studies show that students who are able to use it in a meaningful way achieve consolidating knowledge. They know how to identify their own strengths and weaknesses and are oriented towards improving learning. Reflective practices implemented from the first years should allow working on critical awareness and communication as a dialogue to expand and develop the ability to reflect in and on action and self-regulate during professional development [24].

To promote reflective practice in students, curricular practices are a good opportunity because it is possible to consider aspects of the teaching practice and the competencies necessary and take into account the existing moral codes of practising teachers [25]. At the same time, contact with real experience puts students in a situation that allows them to understand what the practice of the profession entails [26]. However, according to Izadinia [27], it is necessary to improve teacher training so that they can use it as a regular teaching strategy in classrooms even before the student enters in contact with real practice.

The authors argue that the Reflective Practice Questionnaire represents an innovative approach to engaging students in a meaningful way in enhancing teaching and learning and has the potential to reframe the student-teacher relationship into a more collaborative one that goes beyond listening to students. 


\subsection{Hypothesis, Research Questions and Goals}

Hypothesis 1 (H1). Reflective practice used in initial teacher training processes can increase the capacity of critical and reflective thinking and self-appraisal of future teachers.

Research question 1: What are the key competencies that accelerate change in and through higher education (individual knowledge, skills, mindsets and behaviour).

Hypothesis 2 (H2). Regular reflective practice promotes the development of cross-curricular competencies in sustainability that are key to professional performance.

Research question 2: How can we connect higher education with jobs? How can we increase awareness and literacy of the SDGs in higher education and further education?

The main objective to answer these research questions is to analyse the responses of students of the degree in education from three Spanish universities to the Reflective Practice Questionnaire (RPQ). The specific goals are the following:

Examine which the significant subscales of reflection are in accordance with sociodemographic variables.

Identify the correlation between the subscales of the Reflective Practice Questionnaire.

This research aims to contribute to the improvement of the quality in pre-service teacher training by promoting the development of competencies in sustainability and in ESD that are key to professional performance.

\section{Methods}

\subsection{Methods, Design and Settings}

This study was designed as an observational, descriptive, cross-curricular study, using a quantitative methodology. The rationale for using a cross-curricular study lies in the fact that this research obtained information based on data gathered at a specific point in time. The study settings were three different universities (Universitat Autònoma de Barcelona (UAB), (Universitat Internacional de Catalunya (UIC) and Universidade da Coruña (UdC) in Spain. The main criterion for choosing these three universities was of a practical nature: The universities agreed to participate in the research study.

\subsection{Sample}

This is a non-probabilistic sample since it was selected based on purposive selection criteria used for the purpose of determining the participation of the three universities mentioned above. The convenience sample was drawn from 107 undergraduate students. The average age in the sample was 20.04 years old, $95 \%$ of the students were female and $48.6 \%$ were in their first year while $51.4 \%$ were second-year students. The AUB students were in their first year whereas the UIC and UDC students were second-year students.

The criteria for the inclusion of pre-service teachers in the study were the following. The students had to be students at one of the abovementioned universities during academic year 2019-2020, and had to be willing to participate in this study. The criteria for exclusion were not being a student at these universities during the aforementioned academic year and not being willing to participate.

\subsection{Ethical Considerations}

Participation was voluntary and anonymous. The aims and methods of the study were explained to the participants, and they were informed that they could withdraw at any time without having to provide a reason. They were told the electronic data would be stored on the computer of the research team, which was password-protected, and that only the research team would have access to the data, both during and after the study. All the participating students were informed of the fact that their decision about whether to 
participate or not would have no bearing on their marks, and in the event the study was partly or entirely published, their personal information would remain anonymous.

\subsection{Data Collection}

The data were collected between November 2019 and June 2020 (a period that included both semesters). In order to minimise any potential methodological bias, the researchers worked in small teams, in which they decided on the best time to approach the participants, in accordance with their availability. The protocol for completing the questionnaire involved different scenarios, as the students were engaged in different curriculum activities. The students submitted the questionnaire using the Google Forms platform.

\subsection{Instrument Used}

The Reflective Practice Questionnaire (RPQ) by Priddis and Rogers is a questionnaire that was validated through several studies [12-28] and used in different languages, including Swedish [29].

The Priddis and Rogers questionnaire [3] is a 40-item self-report questionnaire divided into 11 subscales: Reflection in Action (Ria), Reflection on Action (RoA), Reflection with Others (RwO), Self-appraisal (SA) Desire for Improvement (Dfl), Confidence-General (CG), Confidence-Communication (CC), Uncertainty (Unc), Stress interacting with Clients (SIC), Job Satisfaction (JS) and Appraisal of Supervision (AS). The RPQ can be used in any profession where interactions with clients occur [28]. Despite the fact that the authors of the RPQ gave us permission to change the word 'clients' for 'students', we decided to leave 'clients' to respect the original questionnaire.

This questionnaire sets itself apart from previous self-report measures of reflective practice because of its ability to be administered to individuals working in any service industry (psychology, nursing, education, amongst others). It will enable future research that can compare and contrast across different contexts and professions [28].

The RPQ is a reliable measure of Cronbach's alpha value $=0.84$ ) [15]. The reliability of reflective capacity and other subscales were determined by calculating their Cronbach alpha values. The RPQ uses the 6-point response scale: (1) Not at all, (2) Slightly, (3) Somewhat, (4) Moderately, (5) Very much and (6) Extremely.

\subsection{Instrument Translation Process}

For the Spanish translation of the instrument, we followed Maneesriwongul's model [30]. The three authors independently translated the original English version into Spanish. After comparing the three sets of translations, they were sent to a bilingual professional translator for back-translation into English. After examining this translation, we developed the final Spanish version.

\subsection{Data Analysis}

Descriptive statistics of quantitative variables are expressed as means \pm standard deviation (SD). Bivariate analysis was performed to compare the subscales with the explanatory variables age, university, course and grade using t-test/ANOVA or the non-parametric Mann-Whitney/Kruskal Wallis test, depending on the characteristics of the data. Normality was tested using the Shapiro-Wilk normality test. $p$ values for pairwise comparisons were adjusted for multiplicity using the Bonferroni correction. The analysis was performed using SAS 9.4 (SAS Institute Inc., Cary, NC, USA). The significance level was set at 0.05 .

\section{Results}

No significant relationship was observed between each of the subscales and the age variable $(p>0.05)$. There were three subscales that did not show statistical difference for any of the Reflection on Action, Reflection with Others and Self-appraisal subscales. However, it showed a statistically significant relationship between the kind of university in seven subscales: (1) Desire for Improvement $(p=0.043)$, (2) Confidence-General $(p=0.014)$, 
(3) Confidence-Communication ( $p=0.021)$, (4) Uncertainty $(p=0.002)$, (5) Stress interacting with Clients $(p=0.001)$, (6) Job Satisfaction $(p<0.001)$ and (7) Appraisal of Supervision $(p=0.026)$. Furthermore, the academic year variable showed statistical significance in four subscales: (1) Reflection in Action $(p=0.044)$, (2) Desire for Improvement $(p=0.016)$, (3) Confidence-General $(p=0.014)$ and $(4)$ Job Satisfaction $(p=0.009)$. All these data are shown in Table 1 below.

\subsection{University}

As far as the university variable is concerned, UIC ranked higher than the other two universities in four subscales: Desire for Improvement $(p=0.043)$ (see Figure 2), Confidence-Communication $p=0.021$, Job Satisfaction $(p<0.001)$ and Appraisal of Supervision $(p=0.026)$. UAB obtained higher scores in one subscale, Confidence-general $(p=0.014)$. UDC ranked higher than the other universities in two subscales (Uncertainty $(p=0.002)$ and Stress interacting with Clients $p=0.001$.

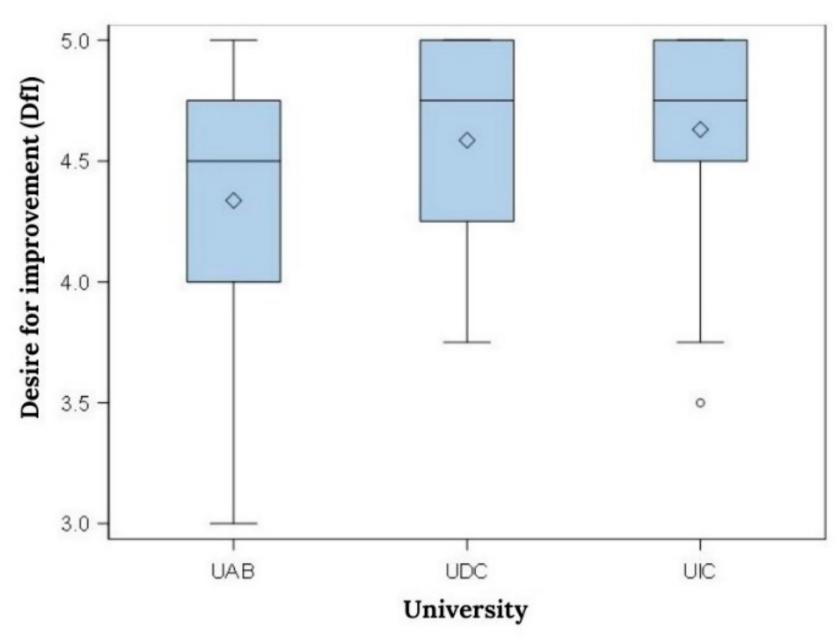

Figure 2. Significant subscale DfI in accordance with the University variable.

\subsection{Academic Year}

With regard to the academic year variable, we found statistical differences between the two academic years in four subscales: Reflection in Action (see Figure 3), Desire for Improvement, Confidence-General and Job Satisfaction. The first-year students obtained higher scores only in Confidence-General $(p=0.014)$.

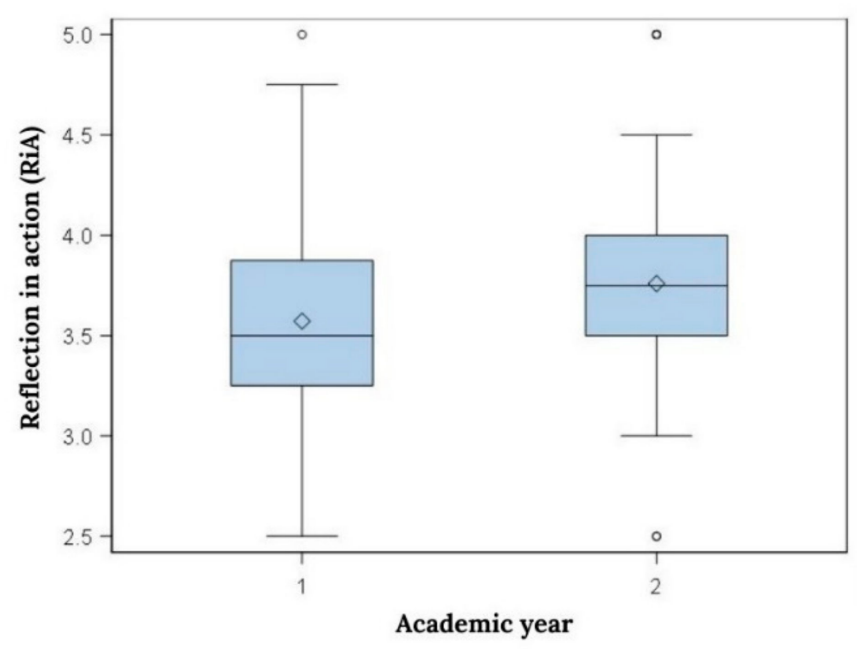

Figure 3. Significant subscale RiA in accordance with the academic year variable. 
The rest of the subscales showing statistcal significance revealed that second-year students scored higher than first-year students. As they have more experience regarding job opportunities, this result was expected. The statistical differences were found in Reflection in Action $(p=0.044)$; Desire for Improvement $(p=0.016)$; and Job Satisfaction $(p=0.009)$.

Descriptive statistics and acceptable Cronbach's alpha values $(>0.70)$ for the RPQ were as follows: Reflection in Action (0.629), Self-appraisal (0.522), Stress interacting with Clients (0.459) and Job Satisfaction (0.308). These low alpha results were expected because these 4 subscales deal directly with questions that involve actively participating in Action and the undergraduate students had not had that experience before. However, the item with the highest average (item \#25) was the same for both first-year and second-year students: 4.67 and 4.88, respectively. The item that attained the lowest score (item \#37) was the same for both first and second-year students: 1.90 and 1.79, respectively. The highest and the lowest item for both academic years were from the same subscale: Job Satisfaction (Table 2).

The results of the Mann-Whitney U test show the following statistically significant differences in accordance with each subscale. Five subscales presented statistical significance in one or more items. The subscale including the most statistically significant items, that is, three items out of four, were the following two: Confidence-General: Item \#2 $(p=0.008)$, item\#17 $(p=0.035)$ and item \#32 $(p=0.035)$ and Job Satisfaction: Item\#10 $(p=0.014)$, item \#18 $(p=0.02)$ and item \#25 ( $p=0.011)$. Two other subscales that had two statistically significant items were: Reflection with Others: Item\#29 $(p=0.020)$ and item\#38 $(p=0.013)$ and Desire for Improvement: Item\#5 $(p=0.035)$ and item\#30 $(p=0.004)$. Finally, one subscale with one statistically significant item was Reflection in Action: Item\#35 ( $p=0.011)$.

There were six subscales without a single significant item: Reflection on Action, SelfAppraisal, Confidence-Communication, Uncertainty, Stress interacting with Clients and Appraisal of Supervision.

\subsection{Correlations between Subscales}

As shown in Figure 4, there are five positive correlations between the following subscales: (1) Reflection on Action and Reflection in Action (0.594), (2) Reflection in Action and Self-Appraisal (0.559), (3) Reflection on Action and Self-appraisal (0.628), (4) Selfappraisal and Confidence-Communication (0.503) and (5) Appraisal of Supervision and Confidence-Communication (0.596). A negative correlation was observed in the subscales of Uncertainty and Confidence-General (-0.529). 
Table 1. Variables and RPQ subscales.

\begin{tabular}{|c|c|c|c|c|c|c|c|c|c|c|c|c|c|c|c|}
\hline & $\mathbf{n}$ & $\mathbf{N}$ & Mean & SD & $\operatorname{RiA}$ & RoA & RO & SA & Dfl & CG & $\mathrm{CC}$ & Unc & SIC & JS & AS \\
\hline & 107 & & & & $p$ value & $p$ value & $p$ value & $p$ value & $p$ value & $p$ value & $p$ value & $p$ value & $p$ value & $p$ value & $p$ value \\
\hline \multirow[t]{3}{*}{ Age } & & & 20.04 & 2.01 & 0.708 & 0.381 & 0.821 & 0.208 & 0.201 & 0.653 & 0.944 & 0.525 & 0.386 & 0.836 & 0.766 \\
\hline & $20-21$ & 34 & & & & & & & & & & & & & \\
\hline & $22+$ & 23 & & & & & & & & & & & & & \\
\hline \multirow[t]{3}{*}{ University } & $\mathrm{UAB}$ & 52 & & & 0.122 & 0.418 & 0.308 & 0.328 & 0.043 * & 0.014 * & 0.021 * & $0.002 *$ & $0.001 *$ & $<0.001 *$ & $0.026^{*}$ \\
\hline & UDC & 32 & & & & & & & & & & & & & \\
\hline & UIC & 23 & & & & & & & & & & & & & \\
\hline \multirow[t]{2}{*}{ Academic year } & $1 \mathrm{st}$ & 52 & & & 0.044 * & 0.287 & 0.204 & 0.208 & $0.016^{*}$ & 0.014 * & 0.836 & 0.647 & 0.592 & 0.009 * & 0.473 \\
\hline & 2nd & 55 & & & & & & & & & & & & & \\
\hline
\end{tabular}

* Indicates significant variable.

Table 2. RPQ questionnaire items regarding the academic year variable.

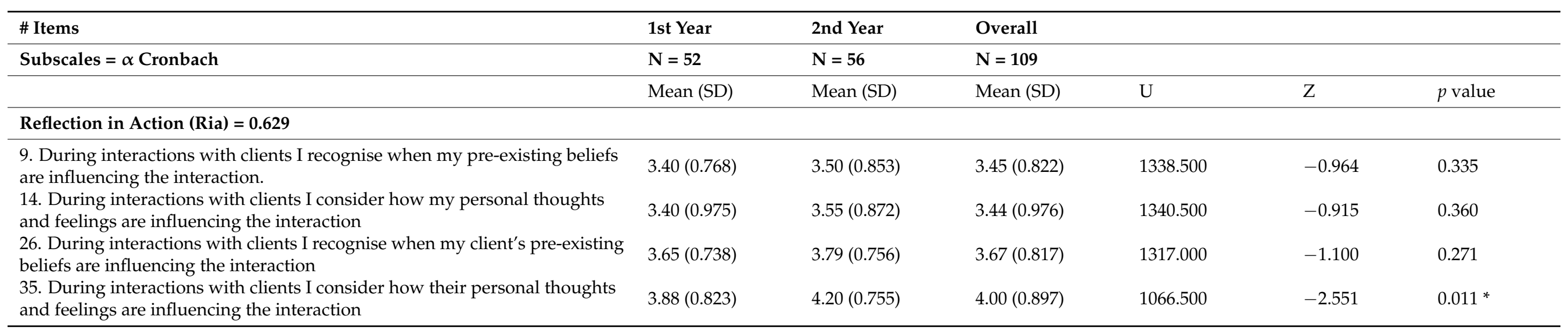


Table 2. Cont.

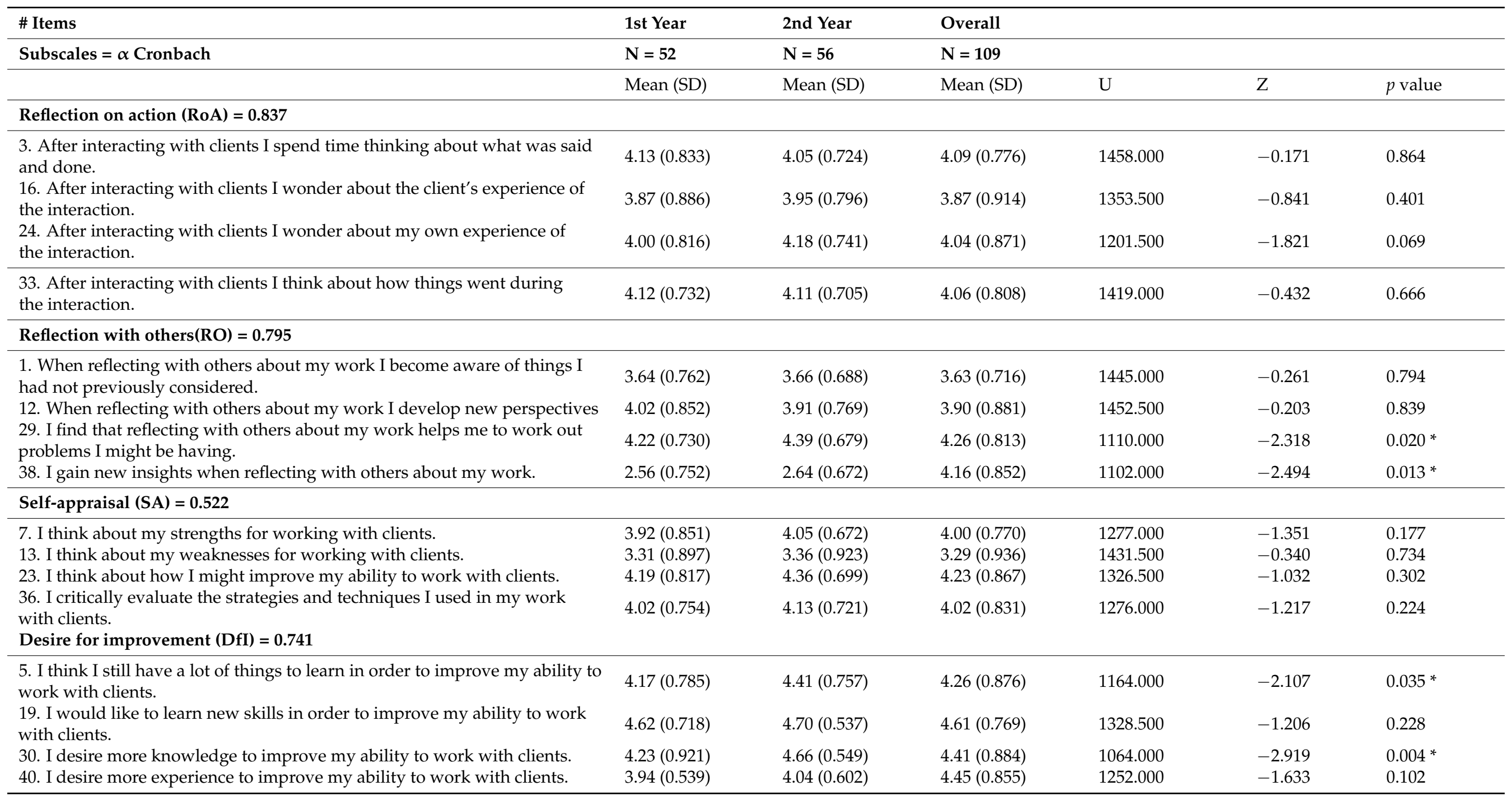


Table 2. Cont.

\begin{tabular}{|c|c|c|c|c|c|c|}
\hline \# Items & 1st Year & 2nd Year & Overall & & & \\
\hline \multirow[t]{2}{*}{ Subscales $=\alpha$ Cronbach } & $\mathrm{N}=52$ & $\mathrm{~N}=56$ & $\mathrm{~N}=109$ & & & \\
\hline & Mean (SD) & Mean (SD) & Mean (SD) & $\mathrm{U}$ & $\mathrm{Z}$ & $p$ value \\
\hline \multicolumn{7}{|l|}{ Confidence-General $=0.857$} \\
\hline \multirow{3}{*}{$\begin{array}{l}\text { 2. I have all the experience I require to effectively interact with clients. } \\
\text { 17. I have all the practical skills I require to effectively interact with clients. } \\
\text { 22. I have learnt everything I need to know in order to effectively interact } \\
\text { with clients. } \\
\text { 32. I have all the theoretical knowledge I require to effectively interact } \\
\text { with clients. }\end{array}$} & $3.49(0.846)$ & $3.09(0.769)$ & $3.26(0.832)$ & 1084.000 & -2.636 & $0.008^{*}$ \\
\hline & $3.71(0.750)$ & $3.27(0.924)$ & $3.42(0.926)$ & 1166.000 & -2.057 & 0.040 * \\
\hline & $3.33(0.944)$ & $2.95(0.942)$ & $3.07(0.988)$ & 1230.500 & -1.614 & 0.107 \\
\hline \multicolumn{7}{|l|}{ Confidence-Communication $=0.753$} \\
\hline $\begin{array}{l}\text { 6. I think I am good at creating a safe environment so that my clients' feel } \\
\text { comfortable enough to share information with me. }\end{array}$ & $4.19(0.681)$ & $4.00(0.714)$ & $4.08(0.696)$ & 1373.000 & -0.737 & 0.461 \\
\hline 11. I feel confident sharing my formulations with clients. & $4.19(0.687)$ & $4.09(0.793)$ & $4.10(0.838)$ & 1462.000 & -0.145 & 0.885 \\
\hline 21. I am good at providing clear messages to my clients. & $4.06(0.639)$ & $3.91(0.721)$ & $3.95(0.786)$ & 1464.500 & -0.131 & 0.896 \\
\hline 34. I am good at listening to my clients with genuine curiosity. & $4.56(0.698)$ & $4.75(0.513)$ & $4.61(0.758)$ & 1230.000 & -1.932 & 0.053 \\
\hline \multicolumn{7}{|l|}{ Uncertainty $($ Unc $)=0.722$} \\
\hline $\begin{array}{l}\text { 8. Sometimes I am unsure if my planning for clients is the best possible way } \\
\text { to proceed }\end{array}$ & $2.85(0.690)$ & $2.86(0.796)$ & $2.83(0.739)$ & 1467.500 & -0.116 & 0.908 \\
\hline 20. Sometimes I am unsure if I am interpreting my clients' needs correctly. & $3.10(0.799)$ & $2.89(0.802)$ & $2.94(0.831)$ & 1427.000 & -0.402 & 0.688 \\
\hline 27. Sometimes I am unsure how to handle the needs of clients. & $2.33(0.678)$ & $2.45(0.685)$ & $2.39(0.706)$ & 1342.500 & -0.945 & 0.344 \\
\hline 31. Sometimes I am unsure that I properly understand the needs of clients & $2.50(0.700)$ & $2.63(0.702)$ & $2.55(0.726)$ & 1295.000 & -1.269 & 0.204 \\
\hline \multicolumn{7}{|l|}{ Stress interacting with clients $(\mathrm{SiC})=0.459$} \\
\hline \multirow{4}{*}{$\begin{array}{l}\text { 4. Sometimes after interacting with a client I feel exhausted. } \\
\text { 15. Sometimes I find interacting with clients stressful. } \\
\text { 28. There are times when I feel distressed after communicating with a client. } \\
\text { 39. The pressure to meet the needs of my clients can sometimes feel } \\
\text { overwhelming. }\end{array}$} & $2.32(0.673)$ & $2.22(0.816)$ & $2.21(0.806)$ & 1275.000 & -1.361 & 0.174 \\
\hline & $2.15(1.243)$ & $2.13(1.440)$ & $2.11(1.336)$ & 1391.000 & -0.600 & 0.549 \\
\hline & $2.08(0.837)$ & $1.95(0.862)$ & $2.02(0.871)$ & 1346.000 & -0.885 & 0.376 \\
\hline & $4.38(0.796)$ & $4.61(0.652)$ & $2.60(0.734)$ & 1409.000 & -0.503 & 0.615 \\
\hline
\end{tabular}


Table 2. Cont.

\begin{tabular}{|c|c|c|c|c|c|c|}
\hline \# Items & 1st Year & 2nd Year & Overall & & & \\
\hline \multirow[t]{2}{*}{ Subscales $=\alpha$ Cronbach } & $\mathrm{N}=52$ & $N=56$ & $\mathrm{~N}=109$ & & & \\
\hline & Mean (SD) & Mean (SD) & Mean (SD) & $\mathrm{U}$ & $\mathrm{Z}$ & $p$ value \\
\hline 10. My work provides me with a lot of fulfilment. & $4.49(0.724)$ & $4.73(0.525)$ & $4.58(0.773)$ & 1154.000 & -2.462 & 0.014 * \\
\hline 18. My work means more to me than simply earning money & $4.37(1.155)$ & $4.63(1.054)$ & $4.46(1.183)$ & 1199.000 & -2.258 & 0.024 * \\
\hline 25. I enjoy my work. & $4.67(0.550)$ & $4.88(0.334)$ & $4.72(0.651)$ & 1183.000 & -2.534 & 0.011 * \\
\hline 37. There are times when I find myself wishing that I did not have to work. & $1.90(0.603)$ & $1.79(0.731)$ & $1.83(0.692)$ & 1320.000 & -1.096 & $0-273$ \\
\hline Appraisal of Supervision (AS) $=0.897$ & & & & & $\mathbf{W}$ & \\
\hline - $\quad$ Confidence as a practitioner & $3.95(0.686)$ & $3.85(0.770)$ & $4.05(0.585)$ & 1277.000 & 2708 & 0.121 \\
\hline - $\quad$ Practical skills & $3.96(0.849)$ & $3.94(0.842)$ & $3.98(0.863)$ & 1407.000 & 2838 & 0.586 \\
\hline - $\quad$ Theoretical knowledge & $3.83(0.636)$ & $3.81(0.786)$ & $3.84(0.458)$ & 1467.000 & 3063 & 0.897 \\
\hline - Ability to be reflective after interactions with clients & $4.13(0.795)$ & $3.98(0.888)$ & $4.27(0.674)$ & 1210.000 & 2641 & 0.067 \\
\hline - Desire to actively develop my professional capabilities & $4.36(0.764)$ & $4.25(0.853)$ & $4.46(0.660)$ & 1260.500 & 2691 & 0.130 \\
\hline
\end{tabular}




\begin{tabular}{|c|c|c|c|c|c|c|c|c|c|c|}
\hline \multicolumn{11}{|c|}{ Pearson's ( $\mathrm{p}$-value) } \\
\hline & RsA & RO & A & VM & SG & SC & $\mathrm{D}$ & $\mathrm{EiC}$ & ST & Sup \\
\hline $\operatorname{ReA}$ & $\begin{array}{r}0.594 \\
(<0.001)\end{array}$ & $\begin{array}{r}0.359 \\
(<0.001)\end{array}$ & $\begin{array}{r}0.559 \\
(<0.001)\end{array}$ & $\begin{array}{l}0.280 \\
(0.003)\end{array}$ & $\begin{array}{c}0.164 \\
(0.091)\end{array}$ & $\begin{array}{r}0.431 \\
(<0.001)\end{array}$ & $\begin{array}{r}-0.103 \\
(0.290)\end{array}$ & $\begin{array}{l}0.009 \\
(0.923)\end{array}$ & $\begin{array}{l}0.263 \\
(0.006)\end{array}$ & $\begin{array}{l}0.308 \\
(0.001)\end{array}$ \\
\hline RsA & 1 & $\begin{array}{r}0.451 \\
(<0.001)\end{array}$ & $\begin{array}{r}0.628 \\
(<0.001)\end{array}$ & $\begin{array}{l}0.331 \\
(0.001)\end{array}$ & $\begin{array}{c}0.158 \\
(0.103)\end{array}$ & $\begin{array}{r}0.482 \\
(<0.001)\end{array}$ & $\begin{array}{r}-0.182 \\
(0.060)\end{array}$ & $\begin{array}{r}-0.126 \\
(0.194)\end{array}$ & $\begin{array}{r}0.280 \\
(0.004)\end{array}$ & $\begin{array}{r}0.418 \\
(<0.001)\end{array}$ \\
\hline RO & & 1 & $\begin{array}{r}0.339 \\
(<0.001)\end{array}$ & $\begin{array}{r}0.412 \\
(<0.001)\end{array}$ & $\begin{array}{c}0.146 \\
(0.133)\end{array}$ & $\begin{array}{r}0.425 \\
(<0.001)\end{array}$ & $\begin{array}{c}-0.208 \\
(0.031)\end{array}$ & $\begin{array}{r}-0.290 \\
(0.002)\end{array}$ & $\begin{array}{c}0.260 \\
(0.007)\end{array}$ & $\begin{array}{r}0.396 \\
(<0.001)\end{array}$ \\
\hline A & & & 1 & $\begin{array}{r}0.368 \\
(<0.001)\end{array}$ & $\begin{array}{l}0.223 \\
(0.021)\end{array}$ & $\begin{array}{r}0.503 \\
(<0.001)\end{array}$ & $\begin{array}{l}-0.180 \\
(0.064)\end{array}$ & $\begin{array}{r}-0.112 \\
(0.251)\end{array}$ & $\begin{array}{r}0.337 \\
(<0.001)\end{array}$ & $\begin{array}{r}0.383 \\
(<0.001)\end{array}$ \\
\hline VM & & & & 1 & $\begin{array}{r}-0.284 \\
(0.003)\end{array}$ & $\begin{array}{r}0.140 \\
(0.151)\end{array}$ & $\begin{array}{l}0.140 \\
(0.151)\end{array}$ & $\begin{array}{r}-0.116 \\
(0.235)\end{array}$ & $\begin{array}{c}0.326 \\
(0.001)\end{array}$ & $\begin{array}{l}0.140 \\
(0.149)\end{array}$ \\
\hline SG & & & & & 1 & $\begin{array}{r}0.462 \\
(<0.001)\end{array}$ & $\begin{array}{l}-0.529 \\
(<0.001)\end{array}$ & $\begin{array}{c}-0.148 \\
(0.128)\end{array}$ & $\begin{array}{l}0.071 \\
(0.465)\end{array}$ & $\begin{array}{r}0.385 \\
(<0.001)\end{array}$ \\
\hline SC & & & & & & 1 & $\begin{array}{r}-0.433 \\
(<0.001)\end{array}$ & $\begin{array}{r}-0.302 \\
(0.002)\end{array}$ & $\begin{array}{r}0.415 \\
(<0.001)\end{array}$ & $\begin{array}{r}0.596 \\
(<0.001)\end{array}$ \\
\hline $\mathrm{D}$ & & & & & & & 1 & $\begin{array}{r}0.361 \\
(<0.001)\end{array}$ & $\begin{array}{r}-0.181 \\
(0.063)\end{array}$ & $\begin{array}{r}-0.438 \\
(<0.001)\end{array}$ \\
\hline $\mathrm{EiC}$ & & & & & & & & 1 & $\begin{array}{r}-0.357 \\
(<0.001)\end{array}$ & $\begin{array}{r}-0.268 \\
(0.005)\end{array}$ \\
\hline ST & & & & & & & & & 1 & $\begin{array}{r}0.399 \\
(<0.001)\end{array}$ \\
\hline Sup & & & & & & & & & & 1 \\
\hline
\end{tabular}

Figure 4. Pearson correlations between the RPQ subscales.

\section{Discussion}

This is the first study carried out in Spain that uses the RPQ with undergraduate preservice teachers. The RPQ proved to be a valid and robust questionnaire for understanding reflective practice as shown in the results obtained. In this section, the results are interpreted from the perspective of the two working hypotheses and research questions we wanted to address. They are related to: (1) Reflective capacity (RC), including RiA, RoA, $\mathrm{RwO}$ and Self-appraisal subscales, and (2) other attributes relevant to $\mathrm{RC}$ that correlate with the four subscales mentioned above.

\subsection{Reflective Capacity (RC): (RiA), (RoA) and (RwO) and Self-Appraisal}

$\mathrm{H} 1$ and Research question 1.

The 21st century approach to teaching requires student-centred pedagogies for authentic learning with desire of improvement, collaboration, communication, self-regulated learning, self-reflection and reflective teaching [31]. However, introducing reflective practice can be a long process, not just for pre-service teachers, but also for in-service teachers. Successful examples of these efforts are found in the fact of encouraging in-service teachers to perform short stays in other countries with different educational systems to test their own personal perceptions with regard to reflective practice [32-34].

In our study, the results showed that Reflection in Action correlates positively with Self-appraisal. Self-appraisal, in turn, was found to have a positive association with both Reflection on Action and Confidence-Communication. Pre-service teachers can benefit from Self-appraisal as a way to deepen their reflection in their practices. In that regard, our study is in line with another studies [35] pointed out. According to them, pre-service teachers increased their ability to reflect on their experiences and teaching behaviour by using practical experiences and making connections between the theory learned in this 
course as well as in previous courses. Other studies show how reflective practice can be improved by the analysis of reflections written down by pre-service teachers [36]. To increase reflective practice, we need to focus on transformative learning, and this only occurs when the learner becomes aware of these frames of reference, which are usually invisible to them, followed by critical reflection with others [32]. Reflection with others plays a key role in increasing reflective practice. War and McCotter introduce four levels, the last one showing the need to have a mentor or critical friend [36] to facilitate and encourage critical thinking. Even though providing feedback can help pre-service teachers in many ways, it does not always facilitate reflection upon students' performance [37]. Yet, without guidance or the opportunity for reflection with others, students produce superficial learning [38]. Smith and Van Egeren [39] noted that social interaction and engagement had been shown to correlate with positive youth outcomes.

When it is not possible to have a mentor or critical friend, self-appraisal comes as a complementary task in hand. According to Moriña and Orozco [40], when they asked students to give their opinion, they observed the happiness and closeness they show, using anecdotal reports, pedagogical documentation, video recording or experiences shared with others [40]. Another study [41] shows how, in order to initiate learners to monitor their learning processes, self-regulation is considered a critical step. To do so, Tuti, Paton and Winters [41] presented three different ways to attain self-regulation: (a) Using cognitive strategies to acquire, store and retrieve information; (b) using metacognitive strategies to plan, monitor and regulate the learning process in order to accomplish a goal; and (c) using resource management strategies to manage time, help, effort, etc., when organising one's study [42]. Challenging students' own assumptions is another way of helping them transform their views. Aslup [43] showed how developing an after-school programme let pre-service teachers experience disequilibrium in their preconceived notions about the self and others and often challenged them.

Teacher Development needs to address the lack of experiences for facilitating and discovering their own and other belief systems, as Baecher and Chung [32] argue, since this will contribute to incorporating new perspectives. Increasing after-school practicum experiences is yet another way of addressing a critical look at pre-service teachers' choice to become teachers and ultimately, "their disposition toward typically marginalised children and schools" [44].

Some of the findings in this study point to positive associations between Reflection on Action and Reflection in Action. However, casual relations cannot be established. It may be said that Reflection on Action helps Reflection in Action, certainly in this study. Placing emphasis on reflection is an integral part of numerous teacher education programmes with the aim to train pre-service teachers to analyse their own teaching [36].

\subsection{Other Attributes Relevant to the Subscales of Reflective Capacity}

$\mathrm{H} 2$ and Research question 2.

According to DESECO [45], cross-curricular competencies include instrumental, interpersonal and systemic competencies that are key to the profession and are related to the subscales [3] included in the RPQ, such as critical thinking and self-awareness, which are fundamental for the development of RC; orientation to learning and quality, linked to the Desire for Improvement; adaptation to the environment and to addressing adversity, linked to the management of Uncertainty and Stress; and interpersonal communication, associated with Appraisal of Supervision and with Confidence-Communication and Confidence-General.

According to the University variable, findings about competencies/attributes (subscales) relevant to subscales of RC show that there are significant differences in the three universities analysed. UIC students ranked higher than the other two with regard to Desire for Improvement, Confidence-Communication, Job Satisfaction and Appraisal of Supervision. At this university, throughout the first year, the students start working on reflection issues in all their subjects. From the first year, they have a personal advisor and 
from the second, mentoring and accompaniment toward professional development. The UAB students scored higher in general confidence. Although this may not be the case here, first-year students tend to exaggerate their level of general confidence. This tendency has also been observed in other degree programmes [32]. Finally, the UdC students obtained better scores for Uncertainty and Stress interacting with Clients, which could be attributed to the fact that they are in their second year and are more aware of the complexity and responsibility involved in teaching.

As far as the academic year is concerned, differences are observed between the first and the second academic year. First-year students attained higher scores in a single subscale, Confidence-General, which is in accordance with the score obtained by the UAB students. Second-year students, on the other hand, achieved higher scores in the following three subscales: Reflection in Action, Desire for Improvement and Job Satisfaction.

Table 1 shows how the significant differences coincide in three subscales, Desire for Improvement, Confidence-General and Job Satisfaction, for the socio-demographic variables of university and academic year. Regarding the Confidence-General subscale, it turns out that second-year students are the ones who obtain the lowest values. This expected coincidence points to the need to develop the key interpersonal communicative competency for training and professional performance.

Significant differences were also observed with regard to the Job Satisfaction subscale in both the academic year and the university variables. It must be pointed out that firstyear students present lower values than second-year students, a fact that coincides with the universities, the UAB (where all the students are first-year students) being the one obtaining the lowest values. Job satisfaction is lower in the first-year students and increases as their reflection and practical experience increase [46].

To achieve continuity between higher education and the professional context, it is necessary to place students in a real or simulated situation that allows them to connect, through reflection, with sustainability skills and competencies related to the job market, and to enable future teachers to become agents of transition toward sustainability. Using reflective practice in higher education becomes a differentiating element for the development of key competencies for sustainable development and for lifelong learning.

Teacher enthusiasm and high levels of emotional intelligence [47] are key factors for effective teaching, promoting teachers' well-being and instructional behaviour and their Job Satisfaction, which is related to their Self-appraisal capacity, Desire for Improvement and Reduction of Stress $[48,49]$.

Students must be agents for change [50]. It is therefore necessary to engage them in a meaningful process to enhance teaching and learning through improving confidence communication that goes beyond listening to them [51]. The COVID-19 pandemic has impacted education at all levels in various ways. Institutions and teacher educators have had to quickly respond to an unexpected and uncertain situation that has generated stress [52]. Practical experiences and feedback from the supervisor or teacher (Appraisal of Supervision) is considered a key mechanism for self-regulated learning (SRL) behaviour (Desire for Improvement) [41].

Pre-service teachers need experiences in practical matters as part of field preparation programmes to gain confidence in their future professional actions. Classroom management and uncertainty (stress) management in front of adverse situations such as the current Covid-19 pandemic is a serious concern for pre-service and beginning teachers and it is necessary to increase pre-service teachers' knowledge and confidence in the use of competencies to control these factors [53]. Classroom management is the most significant cause of concern for pre-service teachers [54], particularly during the practicum [55] and is a deterrent for professional development and Job Satisfaction. Rathel, Drasgow and Christle [46] found that supervisor feedback (Appraisal of Supervision) impacted on the pre-service teachers' communication patterns to drive better classroom management.

A study explores how multiple characteristics (knowledge, beliefs, self-efficacy and self-regulation) of teacher candidates differ qualitatively in their pattern of "starting compe- 
tency", which may have consequences with regard to specific interventions [56]. Different studies [57-59] show the importance reflective practice has for Job Satisfaction and the performance of the teaching profession through adequate management of uncertainty and stress (adaptation to the environment and addressing adversity).

In future research, in order to promote quality education, the relationships between: (1) Uncertainty situations (such as those the pandemic has originated and is currently originating, (2) level of stress and (3) level of reflection capacity (on action, in action and with others) of pre-service or in-service teachers and how all these elements can or cannot generate Desire for Improvement and Job Satisfaction, should be analysed in-depth.

Reflective practice can become a differentiating element to achieve quality education, allowing adaptation to current and future adverse situations.

\subsection{Limitations and Suggestions for Future Research}

There are two major categories of limitations in research studies, threats to internal validity and threats to external validity.

When conducting educational research, we always encounter obstacles that deserve to be mentioned. The limitations of this study can be grouped into limitations of a methodological and technical order (instruments for data collecting), and of an ethical and moral order (consequences for the human being derived from the research itself).

Regarding the limitations of a technical order, this study was carried out with a limited sample in three Spanish universities, although the results and discussion allow us to suggest a potential line of work to jointly develop the competency in education for sustainability, using reflective practice as an instrument for improving critical thinking that drives change towards quality education (SDG 4).

As far as the limitations of an ethical order are concerned, in educational research, the process of construction of knowledge is not neutral and it is inevitable that reality is interpreted from the sensory perception and vision of the world of individuals since reality is not shown independently of them. As a study of human phenomena, we cannot ignore that there are certain limitations that should be noted since it can be difficult to separate real motives and personal perceptions.

Future research would definitely benefit from larger samples and also in other contexts. The cross-sectional study could be carried out in the future at a longitudinal level, so as to see what happens with the participants at the end of their training.

\section{Conclusions}

This study has enabled us to identify reflective practice as a strategy and leverage point to accelerate change in and through higher education. It is important for pre-service and in-service teachers to be able to recognise the influence of beliefs, personal thoughts and feelings, both of oneself and of others, weaknesses and strengths, stress management, and the importance of communication in the process of learning and teaching. They need to be able to act in accordance with the needs of a given context to improve professional performance and quality education (SDG 4). Reflective practice is an instrument that contributes to this self-awareness process.

ESD reflects the concern for high-quality education (SDG 4) that helps people understand what is happening (knowing), feel part of the society in which they live (knowing how to be) and know how they can actively participate at a personal and professional level (know-how). ESD requires participatory methods that motivate and empower students to change their behaviour and promotes the acquisition of competencies such as critical and reflective thinking, managing uncertainty and making decisions in a certain context.

Competency training and the development of key competencies such as reflective and critical thinking and self-knowledge, which entails self-appraisal processes, are essential for quality education. It is therefore important to incorporate strategies that promote the students' development of reflective capacity, $\mathrm{RiA}, \mathrm{RoA}$ and $\mathrm{RwO}$, at an individual and collaborative level from the beginning of their training at university. However, reflective 
practice must be accompanied by processes of communication as a dialogue and of supervision that encourage confidence, the desire to improve and job satisfaction. Otherwise, it can be a source of stress. If the students' reflective capacity increases, they manage uncertainty better, and training future teachers in reflective practice should therefore become a differentiating element to achieve quality education, allowing adaptation to current and future adverse situations.

The research questions of the study can be relevant to teacher training institutions around the world with relation to the importance of SDG 4 and the innovation that it provides.

The contribution and the value of the study reflects the concern for high-quality education that helps people to understand what is happening (know), to feel part of the society they live in (know how to be) and to know how they can actively participate on a personal and professional level (know how to do), and this is precisely the value of the study.

Author Contributions: Conceptualization, M.T.F.-C., C.D.-O. and I.Á.-C.; methodology. I.Á.-C. and M.T.F.-C.; validation, M.T.F.-C. and I.Á.-C.; formal analysis, M.T.F.-C., and I.Á.-C.; investigation, M.T.F.-C., C.D.-O. and I.Á.-C.; resources, M.T.F.-C., C.D.-O. and I.Á.-C.; data curation, M.T.F.-C., C.D.-O. and I.Á.-C.; writing-original draft preparation, M.T.F.-C. and I.Á.-C.; writing-review and editing, M.T.F.-C. and I.Á.-C.; visualization, M.T.F.-C. and I.Á.-C.; supervision, M.T.F.-C. and I.Á.-C.; project administration, M.T.F.-C.; funding acquisition, M.T.F.-C. and I.Á.-C. All authors have read and agreed to the published version of the manuscript.

Funding: This research was funded by the government of Catalonia and AGAUR in the call for the ARMIF 2017 project "Work-linked training: a space for research and the construction of professional knowledge" [Ref. 2017 ARMIF 00001].

Institutional Review Board Statement: Student consent was waived because the Reflective Practice Questionnaire used for the research was anonymous. No personal student data were included in the study.

Informed Consent Statement: Not applicable.

Data Availability Statement: The data presented in this study are available on request from the corresponding author. Data available on request due to restrictions privacy.

Acknowledgments: We would like to thank Ann Swinnen for her feedback and comments and also gratefully acknowledge the support of the Integral Research Group on Sustainability and Education (SEI in Spanish) of the Universitat Internacional de Catalunya (2017 SGR 119).

Conflicts of Interest: The authors declare no conflict of interest.

\section{References}

1. UNESCO. Incheon Declaration and Framework for Action for the Implementation of SDG 4; UNESCO: Paris, France, 2016. Available online: https:/ / unesdoc.unesco.org/ark:/48223/pf0000245656/PDF/245656eng.pdf.multi (accessed on 14 April 2020).

2. United Nations (UN). Shared Responsibility, Global Solidarity: Responding to the Socio-Economic Impacts of COVID-19. New York. 2020. Available online: https:/ / unsdg.un.org/sites/default/files/2020-03/SG-Report-Socio-Economic-Impact-of-Covid19. pdf (accessed on 14 April 2020).

3. Priddis, L.; Rogers, S.L. Development of the reflective practice questionnaire: Preliminary findings. Reflective Pract. 2017, 19, 89-104. [CrossRef]

4. UNESCO. Education for Sustainable Development Goals: Learning Objectives; UNESCO: Paris, France, 2017. Available online: http:/ / unesdoc.unesco.org/images/0024/002474/247444e.pdf (accessed on 14 April 2020).

5. Fernández, M.; Fuertes, M.; Albareda, S. Sostenibilización curricular en la educación superior: Propuesta metodológica. Opción 2015, 31, 284-304.

6. Wiek, A.; Withycombe, L.; Redman, C.L. Key competencies in sustainability: A reference framework for academic program development. Sustain. Sci. 2011, 6, 203-218. [CrossRef]

7. De Haan, G. The development of ESD-related competencies in supportive institutional frameworks. Int. Rev. Educ. 2010, 56, 315-328. [CrossRef]

8. Rieckmann, M. Future-oriented higher education: Which key competencies should be fostered through university teaching and learning? Futures 2012, 44, 127-135. [CrossRef] 
9. Fuertes, M.T. Modelo de sistematización en los proyectos sociales de ApS (UIC). Hist. Comun. Soc. 2014. [CrossRef]

10. UNESCO. Shaping the Future We Want. Un Decade of Education for Sustainable Development (2005-2014); Final Report; UNESCO: Paris, France, 2014. Available online: http:/ / unesdoc.unesco.org/images/0023/002301/230171e.pdf (accessed on 14 April 2020).

11. Weinert, F.E. Concept of competence: A conceptual clarification. In Defining and Selecting Key Competencies; Rychen, D.S., Salganik, L.H., Eds.; Hogrefe \& Huber Publishers: Boston, MA, USA, 2001; pp. 45-65.

12. Anderman, L.H.; Andrzejewski, C.E.; Allen, J. How Do Teachers Support Students' Motivation and Learning in Their Classrooms? Teach. Coll. Rec. 2011, 113, 969-1003.

13. Schön, D.A. El Profesional Reflexivo; Paidós: Barcelona, Spain, 1998.

14. Rogers, S.; Priddis, L.; Michels, N.; Tieman, M.; Winkle, L.J. Applications of the reflective practice questionnaire in medical education. BMC Med. Educ. 2019, 19, 47. [CrossRef]

15. Schön, D. The Reflective Practitioner: How Professionals Think in Action; Basic Books: New York, NY, USA, 1983.

16. Schön, D. Educating the Reflective Practitioner: Toward a New Design for Teaching and Learning in the Professions; Jossey-Bass: San Francisco, CA, USA, 1987.

17. Farrell, T.S.C. TESOL, a profession that eats its young! The importance of reflective practice in language teacher education. Iran. J. Lang. Teach. Res. 2016, 4, 97-107. Available online: http:/ / www.urmia.ac.ir/ijltr (accessed on 18 May 2020).

18. Pretorius, L.; Ford, A. Reflection for learning: Teaching reflective practice at the beginning of University Study. Int. J. Teach. Learn. High. Educ. 2016, 28, 241-253. Available online: http:/ / www.isetl.org/ijtlhe/ (accessed on 18 May 2020).

19. Körkkö, M.; Kyrö-Ämmälä, O.; Turunen, T. Professional development through reflection in teacher education. Teach. Teach. Educ. 2016, 55, 198-206. [CrossRef]

20. Kaymakamoglu, S.E. In search of developing practical knowledge in pre-service EFL teachers: A proposed model. J. Lang. Linguist. Stud. 2019, 15, 1000-1010. Available online: http://jlls.org/index.php/jlls/article/view/1382/506 (accessed on 18 May 2020). [CrossRef]

21. Song, J.; Sharma, U.; Choi, H. Impact of teacher education on pre-service regular school teachers' attitudes, intentions, concerns and self-efficacy about inclusive education in South Korea. Teach. Teach. Educ. 2019, 86, 102901. [CrossRef]

22. Efe, R. The relation between science student teachers' approaches to studying and their attitude to reflective practice. Int. Educ. Stud. 2018, 11, 54-62. [CrossRef]

23. Gungor, M.N. Turkish pre-service teachers' reflective practices in teaching english to young learners. Aust. J. Teach. Educ. 2016, 41, 136-151. [CrossRef]

24. Hernández-Pina, F.; Rosário, P.; Cuesta Sáez de Tejada, J.D. Impacto de un programa de autorregulación del aprendizaje en estudiantes de Grado. Rev. Educ. 2010, 353, 571-588.

25. Carter-Andrews, D.J.; Bartell, T.; Richmon, G. Teaching in dehumanizing times: The professionalization imperative. J. Teach. Educ. 2016, 67, 170-172. [CrossRef]

26. Ye, W.; Law, W.W. Pre-service teachers' perceptions of teachers' morality in China. Teach. Teach. Educ. 2019, 86, 102876. [CrossRef]

27. Thompson, M.; Schademan, A. Gaining fluency: Five practices that mediate effective co-teaching between pre-service and mentors teachers. Teach. Teach. Educ. 2019, 86, 102903. [CrossRef]

28. Izadinia, M. Preservice teachers' professional identity development and the role of menor teachers. Int. J. Mentor. Coach. Educ. 2016, 5, 127-143. [CrossRef]

29. Gustafsson, S.; Engström, A.; Lindgren, B.; Gabrielsson, S. Reflective capacity in nurses in specialist education: Swedish translation and psychometric evaluation of the Reflective capacity scale of the reflective practice questionnaire. Nurs. Open 2020, 1, 1-7. [CrossRef]

30. Maneesriwongul, W. Instrument translation process: A methods review. J. Adv. Nurs. 2004, 48, 175-186. [CrossRef]

31. Giroux, H.A. When schools become dead zones of the imagination: A critical pedagogy manifesto. In The Wiley Handbook of Global Educational Reform; John Wiley \& Sons, Inc.: Hoboken, NY, USA, 2018; pp. 503-515. [CrossRef]

32. Baecher, L.; Chung, S. Transformative professional development for in-service teachers through international service learning. Teach. Dev. 2020, 24, 33-51. [CrossRef]

33. Poorchanginzi, B.; Farokhzadian, J.; Abbaszadeh, A.; Mirzaee, M.; Borhani, F. The importance of professional values from clinical nurses' perspective in hospitals of a medical university in Iran. BMC Med. Ethics 2017, 18, 20. [CrossRef]

34. Bleda, S.; Álvarez, I.; Prat, M. The perceptions of professional values among students at a Spanish Nursing School. Healthcare 2020, 8, 74. [CrossRef]

35. Scharfenberg, F.J.; Bogner, F.X. A role-play-based tutor training in preservice teacher education for developing procedural pedagogical content knowledge by optimizing tutor-student interactions in the context of an outreach lab. J. Sci. Teach. Educ. 2019, 30, 461-482. [CrossRef]

36. Yuan, R.; Mak, P. Reflective learning and identity construction in practice, discourse and activity: Experiences of pre-service language teachers in Hong Kong. Teach. Teach. Educ. 2018, 74, 205-214. [CrossRef]

37. Yusuf, F.; Widiati, U.; Sulistyo, T. Multimodal feedback provision in improving pre-service teachers' competence. Indones. J. Appl. Linguist. 2017, 7, 239-246. [CrossRef]

38. Tiainen, O.; Korkeamäki, R.-L.; Dreher, M.J. Becoming reflective practitioners: Case study of three beginning pre-service teachers. Scand. J. Educ. Res. 2017, 62, 586-600. [CrossRef] 
39. Smith, C.; Van Egeren, B. Bringing in the Community: Partnerships and Quality Assurance in 21st Century Community Learning Centers. After-School Matters Occasional; Paper Series \#9; The Robert Browne Foundation and the National Institute on Out-of-School Time: Wellesley, MA, USA, 2008.

40. Moriña, A.; Orozco, I. Understanding inclusive pedagogy in primary education: Teacher's perspectives. Educ. Stud. 2021, 42, 137-151. [CrossRef]

41. Pintrich, P.R. The role of goal orientation in self-regulated learning. In Handbook of Self-Regulation; Academic Press: San Diego, CA, USA, 2000; pp. 451-502. [CrossRef]

42. Tuti, T.; Paton, C.; Winters, N. The counterintuitive self-regulated learning behaviours of healthcare providers from low-income settings. Comput. Educ. 2021, 166, 104136. [CrossRef]

43. Aslup, J. Teacher Identity Discourses: Negotiating Personal and Professional Spaces; Erlbaum Associates: Mahwah, NJ, USA, 2006.

44. Dell'Angelo, T.; Seaton, G. Students and Teachers co-constructing identity. J. Urban Learn. Teach. Res. 2016, 12, 124-132.

45. OCDE-DESECO. Definition and Selection of Competences: Theoretical and Conceptual Fundations. Summary of the Final Report "Key Competencies for a Successful Life and a Well-Functioning Society"; OCDE: Paris, France, 2003.

46. Downs, K.R.; Cladarella, P.; Larsen, R.A.A.; Charlton, C.; Wills, H.; Kamps, D. Teacher praise and reprimands: The differential respone of students at risk of emotional and behavioral disorders. J. Posit. Behav. Interv. 2019, 21, 135-147. [CrossRef]

47. Turner, K.; Stough, C. Pre-service teachers and emotional intelligence: A scoping review. Aust. Educ. Res. 2020, 47, 283-305. [CrossRef]

48. Burić, I.; Moe, A. What makes teachers enthusiastic: The interplay of positive affect, self-efficacy and job satisfaction. Teach. Teach. Educ. 2020, 89, 103008. [CrossRef]

49. Lopes, J.; Oliveira, C. Teacher and school determinants of teacher job satisfaction: A multilevel analysis. Sch. Eff. Sch. Improv. 2020, 31, 641-659. [CrossRef]

50. Healey, M.; Jenkins, A. The role of academic developers in embedding high-impact undergraduate research and inquiry in mainstream higher education: Twenty years' reflection. Int. J. Acad. Dev. 2018, 23, 52-64. [CrossRef]

51. Jensen, K.; Bennett, L. Enhancing teaching and learning through dialogue: A student and staff partnership model. Int. J. Acad. Dev. 2016, 21, 41-53. [CrossRef]

52. Carrillo, C.; Flores, C. COVID-19 and teacher education: A literature review of online teaching and learning practices. Eur. J. Teach. Educ. 2020, 43, 466-487. [CrossRef]

53. Jackson, C.; Simoncini, K.; Davidson, M. Classroom profiling training: Increasing preservice teachers' confidence and knowledge of classroom management skills. Aust. J. Teach. Educ. 2013, 38, 30-46. [CrossRef]

54. Bromfield, C. PGCE secondary trainee teachers and effective behaviour management: An evaluation and commentary. Support Learn. 2006, 21, 188-193. [CrossRef]

55. Mehrpour, S.; Moghaddam, M. Exploring novice and experienced Iranian EFL teachers' beliefs representations: A more vivid picture. Int. J. Lang. Stud. 2018, 12, 17-50.

56. Holzberger, D.; Maurer, C.; Kunina-Habenicht, O.; Kunter, M. Ready to teach? A profile analysis of cognitive and motivationalaffective teacher characteristics at the end of pre-service teacher education and the long-term effects on occupational well-being. Teach. Teach. Educ. 2021, 100, 103285. [CrossRef]

57. Simsek, U.; Yildirim, E.; Öntas, T. First-year experiences of Social Studies Teachers starting their profession in the public sector. Int. J. Educ. Methodol. 2021, 7, 171-185. [CrossRef]

58. Tracey, M.W.; Hutchinson, A. Uncertainty, reflection, and designer identity development. Des. Stud. 2016, 42, 86-109. [CrossRef]

59. Sinner, A. Transitioning to teacher: Uncertainty as a game of dramatic hats. Teach. Teach. 2012, 18, 601-613. [CrossRef] 